Marcin Grygiel

University of Rzeszów

e-mail: mgrygiel@poczta.fm

ORCID: 0000-0002-8084-8137

\title{
THE COGNITIVE MOTIVATION BEHIND THE SEMANTICS OF HUNGARIAN CO-VERBIAL CONSTRUCTIONS WITH ÖSSZE AND SZÉT
}

\begin{abstract}
The use of an elaborate system of co-verbial constructions is the hallmark of the Hungarian language and one of the biggest challenges a translator or a learner of this language has to face. Co-verbial constructions consist of verbs, or their derivates, accompanied by a limited number of prefixes or particles that modify their meanings. They not only perform numerous syntactic and lexical functions, which is important in terms of language production, but also are able to change the meaning of the verb completely. The aim of this study is to trace the cognitive motivation behind the use of Hungarian co-verbial constructions with össze/szét and to show that the meanings developed by these constructions can be organized with reference to prototypical scenes structured in the form of a radial category.

Keywords: Hungarian, co-verbial constructions, preverbs, verbal prefixes, polysemy, semantic extension, cognitive linguistics, cognitive motivation, scenes, radial category.
\end{abstract}

\section{Introduction}

Proponents of Cognitive Linguistics make a strong claim for the pervasiveness of motivation in natural language (Lakoff, 1987; Lehmann, 2007; Panther \& Radden, 2011; Panther 2013). Radden and Panther (2004) distinguish four major types of motivation: ecological motivation, i.e. motivation of a linguistic unit due to its place, or ecological niche, within a system; genetic motivation, i.e. motivation of present-day linguistic behavior or structure due to historical factors; experiential motivation, i.e. motivation that is based on embodied experience; and cognitive motivation, i.e. motivation that is based on human knowledge and cognitive operations such as metonymy and metaphor. More specifically, cognitive factors that may have a motivational impact on language structure include the human abil- 
ity to develop and access knowledge structures such as categories, frames, scenes and mental spaces (Radden \& Panther, 2004, p. 29).

However, in the majorityof the linguistic literature on the subject, most of the attention dedicated to the study of motivation in language has beenfocused on English or other Indo-European languages (Nuyts, 2007, p. 553; Langacker 2011, p. 31). Very few studies provide data from languages where less prototypical conceptualizations are more likely to take place. Hungarian, with its numerous linguistic peculiarities, is undoubtedly a representative of the latter category and can be treated likea treasure trove of still largely unexplored culture-specific concepts that wait to be discovered by cognitive linguists. ${ }^{1}$ Of course, this does not mean that studies of non-IndoEuropean languages carried out within the cognitive linguistic paradigm are rare or that Hungarian is not studied by cognitive and functional linguists (e.g. Imrényi et al., 2017).

The aim of the present paper is to trace the cognitive motivation behind the emergent meanings in össze/szét-based Hungarian co-verbial constructions and to assert that this kind of motivation is intrinsically related to experiential motivation which, in turn, results from the most basic experiences of our bodily interaction with the environment. Unlike most other languages, however, where such contrasts as UP/DOWN, FRONT/BACK, and ABOVE/UNDER are heavily explored on the linguistic level, Hungarian co-verbial constructions with össze and szét are primarily motivated by the bodily movement of arms and can be briefly expressed as the opposition between the meanings of TOGETHER and APART.

\section{Methodology}

As far as the methodology applied in the study is concerned, the focus here will be put on the qualitative analysis of the aforementioned linguistic units accompanied by a corpus data-driven study, the aim of which is to reveal the units' meaning potentials. In this respect, our primary source of language material is the new, expanded version of the Hungarian National Corpus and the Hungarian Web Corpus (huTenTen12). In the latter case, we also rely on quantitative concordance and frequency data. The frequency of an expression in the corpus has often been investigated as one possible way to operationalize the conventionality of the expression in the community (e.g. Biber \& Conrad, 1999; Stefanowitsch, 2006). However, it should be noted that frequency itself is problematic in this sense, as argued, for instance, by Schmid (2010). As a result, in order to support our claims con- 
cerning the entrenchment/salience of the prototypical scenes, we also rely on pedagogical textbooks and lexicographical sources to demonstrate that the prototypical scenes are well entrenched in the memory of the speakers. The illustrative language material, on the other hand, comes from the two Hungarian corpora whose history and tools are shortly described in the following two paragraphs.

Work on the Hungarian National Corpus (HNC) started in 1998 at the Department of Corpus Linguistics of the Research Institute for Linguistics of the Hungarian Academy of Sciences. HNC currently contains 187.6 million words. ${ }^{2}$ It is divided into five subcorpora by regional language variants and into five subcorpora by text genres. The objective behind the project was to create a balanced reference corpus of the present-day Hungarian language (Váradi, 2002; Sass, 2008). Since March 2008, HNC includes a separate Verb Argument Browser tool for investigating the argument structure of Hungarian verbs. This additional analytical device is very important for the study of co-verbial constructions as they very often interfere with argument structure and play a role in determining the situation aspect (telicity) of the predicate phrase (Surányi, 2009).

The Hungarian Web Corpus (huTenTen12), in contrast, is a much larger language corpus in comparison with $\mathrm{HNC}$, and it consists of a body of texts written in Hungarian that have been collected from the Internet. The huTenTen12 corpus is included in Sketch Engine and belongs to the TenTen corpus family, which is a set of the web corpora built using the same methodology with a target size of $10+$ billion words. ${ }^{3}$

\section{The category of co-verbial constructions in Hungarian}

Co-verbial constructions are restricted combinations of two, or sometimes more than two, elements - a main verb and co-verbial modifiers (also known as co-verbs or detachable prefixes) - that can additionally function as unbound particles. ${ }^{4}$ Co-verbial modifiers express meanings such as the direction of motion, the manner of an action, and the beginning or completion of an action (aspect)..$^{5}$ As the examples below show, the meanings expressed by Hungarian co-verbial modifiers can be treated as metaphorical extensions of spatial directions that tend to indicate the point of departure, destination or other physical parameters of a movement or activity, for example, its localization. Thus, the spatial grounding with which they are associated serves as the most likely source domainin the complex semantic structure of co-verbial constructions formed by them: 


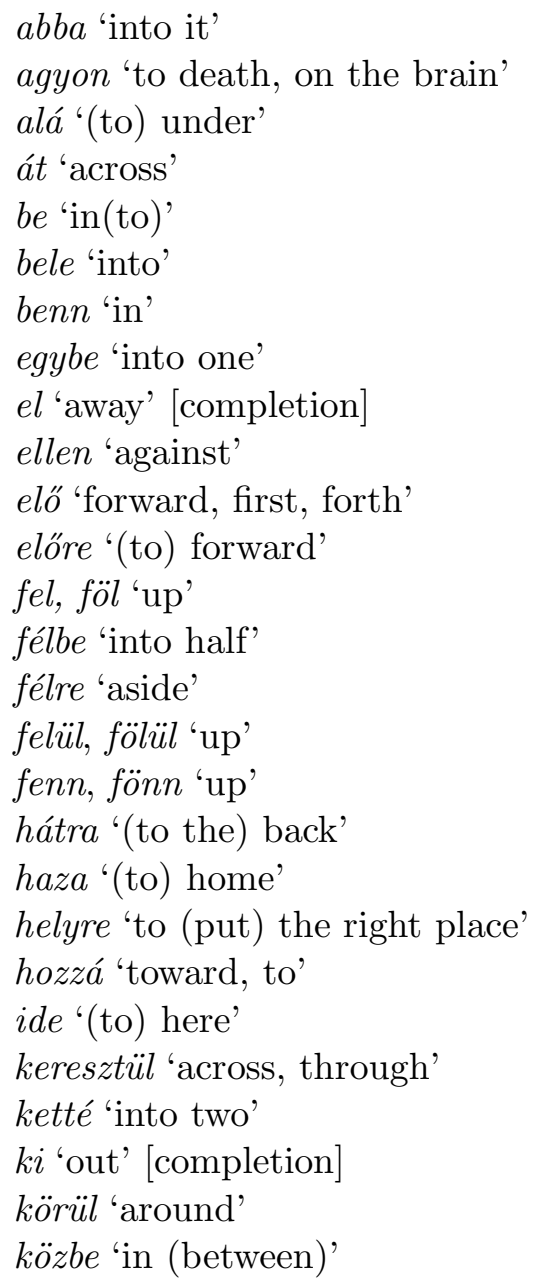

közre 'in (between)'

külön 'apart'

le 'down'

meg [perfective, historically 'backward movement']

mellé 'next to, not to the right place' neki 'into, against a surface'

oda '(to) there'

össze 'together'

rá 'onto'

rajta 'on'

széjjel 'apart'

szembe 'opposite, in the face of'

szerte 'in all directions'

szét 'apart'

tele 'full'

tova 'away'

tovább 'continuing (on), further'

tönkre 'to ruin'

túl 'over, past, beyond'

újjá 'anew'

újra 'again'

utána 'after'

végbe 'to the end'

végig 'throughout'

vissza 'back' ${ }^{6}$

The main reason why co-verbial constructions are so challenging is that, despite their obvious syntactic complexity, they often show traits of being lexically complex units. In a nutshell, co-verbial constructions can be schematized as verbs (or their derivatives) modified by a limited number of additional elements whose intrinsic meaning is associated with the expression of spatial relations. Thus, co-verbial constructions are not completely new lexical units, but rather new combinations of already existing words. Co-verbial modifiers can not only introduce subtle semantic modifications (e.g. alszik 'to sleep' vs. elalszik 'to fall asleep') but even change the meaning of the verb entirely (e.g. ad 'to give' vs. elad 'to sell'). Moreover, they are frequently polysemous and their semantic structures exhibit the effects of a radial category (Lakoff, 1987; Lewandowska-Tomaszczyk, 2007). 
The cognitive motivation behind the semantics of Hungarian co-verbial...

The meaning and use of co-verbial constructions can be shaped by not only metaphorical but also metonymic processes. For example, as claimed by Grygiel (2018a), in both Hungarian and English, as a result of the PART FOR WHOLE metonymic transfer, many co-verbial modifiers can function on their own as if they were main verbs:

(1) Kalandra fel! (lit. adventure-to up) 'It's time for adventures!'

(2) Le a kalappal elötted! (lit. down hat-with before-you) 'Hats off to you!'

(3) Le az árulókkal! 'Down with the traitors!'

Furthermore, Rákosi et al. (2011) show that Hungarian co-verbial constructions resemble English phrasal verbsin many ways. ${ }^{7}$ For example, in sentence (4) belowthe co-verbial construction is non-compositional in both languages:

(4) János feladta a harcot. (lit. John up-give-past.3sg the fight-acc) 'John gave up the fight.'

There is no reasonable semantic computation that derives the meaning 'abandon' for give up from the meaning of the base verb and the co-verbial modifier. Of course, this does not mean that it is not motivated. In addition, the particle verb formation changes the argument structure of the verbal stem: whereas give is a three-place predicate, give up is diadic, the dative beneficiary argument having been removed from the argument structure. Furthermore, Hungarian particle verbs serve very productively as input forlexical processes, eg. a feladhatatlan harc (lit. the up-give-able not fight) 'the fight that cannot be given up' (Rákosi et al., 2011, p. 81).

\section{The meaning of össze/szét when used as separate words}

According to the MNÉS dictionary, the co-verbial modifier össze is used on its own without a main verb very rarely or only in archaic/dialectal contexts. If it does appear as a separate word, its meaning can be translated as 'together' or 'to get together' and it is mostly used with duplication in calls for action:

(5) Ne húzódjatok úgy el egymástól! Össze, össze! 'Don’t get so far apart! Together, together!' (MNÉS)

The same lexicographic source (MNÉS) informs us that a similar set of restrictions on use apply to the co-verbial szét, which only occasionally appears without a main verb. If it is used as a separate lexical item, its 
meaning refers to, for instance, 'being divorced after previous reunion, separation into two or in multiple directions':

(6) A lövésre elfutottak az emberek, szét, a szélrózsa minden irányában. 'After hearing the sound of shooting, people ran away, apart, in all directions of the rose of winds.' (MNÉS)

(7) Szét gyáva nép - el Fáraó lakától! 'Apart cowardly people - away from Pharaoh's house!' (MNÉS)

It is interesting to notice that both co-verbial modifiers - össze and szét - when used as independent lexical items, to a large extent, behave like or even replace main verbs. Notice that in example (6), szét can be interpreted as an additional or alternative co-verbial modifier that, very much like the co-verbial modifier el 'away', goes together with the verb futtottak 'they ran', rather than as a word used on its own.

\section{Prototypical scene No. 1}

One of the most basic facts, observed after even a very cursory analysis of the examples provided for the össze/szét entries in both HNC and huTenTen12, is the existence of a diversity of related meanings expressed by the same co-verbial construction and aneven larger network of meanings in the case of the co-verbial constructions formed by means of each of the co-verbial modifiers separately. It seems, however, that these meanings can be organized in a radial chain of scenes when we apply such fundamental notions from Cognitive Linguistics as "prototype effects" (Rosch, 1973), "radial category" (Lakoff, 1987) and "scene" (Fillmore, 1985) to the analysis. Here we would like to test the hypothesis that individual meanings in össze/szét co-verbial constructions, delineated by the contours of their contextual usage evidenced in the HNC and huTenTen12 corpora, can be grouped into a chain of prototypical scenes which act as images that motivate these meanings.

A deeper analysis of HNC and huTenTen12 contexts, which also takes into consideration frequency data, may suggest that the primary scene behind the use of most co-verbial constructions with össze/szét is the movement of arms toward the body's center and spreading them apart in the opposite direction. This kind of scene has a dynamic and, at the same time, imagistic or image-like character. This is why the concept of a scene seems to best represent it. Moreover, the concept of a prototypical scene used here stands very close to Grady's (1997) and Grady and Johnson's (1997) understanding 
of "primary scenes" composed of correlated subscenes whose main function is to motivate conceptual metaphors. Grady (1997, pp. 23-24) defines primary scenes as "subjective (phenomenological) experiences of a basic event" and claims that they are "universal elements of human experience, defined by basic cognitive mechanisms and abilities, which relate in some salient sense to goal-oriented interaction with the world".

The Sketch Engine Concordance provides 141 contexts for the combination of szét 'apart' and kar 'arm', which gives a 0.04 per million ratio in huTenTen12. Most of the contexts contain various forms of the expression összefonja a karjait 'to fold one's arms' (126), but the expressions összefüzi a karjait 'to tie one's arms' (3), erösen összezárja a karjait 'to strongly close one's arms' (1) and others are also found. The same search for összefon 'to fold' and kar 'arm' gives 654 contexts ( 0.21 per million) compared to 3521 contexts for összefon 'to fold' (1.03 per million) and 899,301 contexts for össze (284.42 per million).

In the case of the co-verbial modifier szét, the Sketch Engine Concordance provides 326 contexts for the combination of szét 'apart' and kar 'arm', which gives a 0.1 per million ratio in huTenTen12. All of the contexts contain various forms of the expression széttárja a karjait 'to spread one's arms'. The same search for széttár 'to spread'and kar 'arm' gives 1,454 contexts (0.46 per million) compared to 7,687 contexts for széttár 'to spread' (2.43 per million) and 131,813 contexts for szét (41.69 per million).

The frequency data given above show that prototypical scene No. 1 is well entrenched in the memory of the speakers, even though the össze/szét + kar combination is definitely not the most frequently produced collocation with the co-verbial modifiers össze/szét. Nevertheless, our hypothesis that arm movement should be treated as a primary source of motivation for other scenes and conceptualizations behind the meanings expressed by the co-verbial modifiers össze/szét appearsto be further supported by cognitive, developmental and purely linguistic evidence. Notice that we experience the reality that surrounds us primarily through our bodies; the first meanings of össze/szét that are to be learned by a baby or child can only be expressed by means of bodily movements. Moreover, in the process of acquiring Hungarian as a foreign language by adult learners, the association of össze/szét with moving one's arms or other body parts is frequently introduced at early stages of teaching/learning. ${ }^{8}$

By metonymic and metaphorical extensions, or, in other words, by means of cognitive motivation, prototypical scene No. 1 can be used as a model for the other prototypical scenes. But it can also be transferred onto a series of conceptualizations more directly associated with prototyp- 
ical scene No. 1. This leads to the rise of co-verbial constructions whose meanings refer to other body parts (not only arms but also legs, fingers, hands) and situations where parts of a bigger whole are either joined together or separated. This can be testified by the following HNC contexts:

(8) Mária nem tud szólni, cask áll, össze fonja az ujjait. 'Mária can’t speak, she is just standing and twiddling her fingers.' (HNC)

(9) Sikeresen választottak szét kétéves, fejüknél összenött pakisztáni sziámi ikreket. 'The two-year-old Pakistani Siamese twins, whose heads grew together, were successfully separated.' (huTenTen12)

The meaning of 'joining parts together' can be further traced in co-verbial constructions such as összeszerel 'to install, to fit/put sth together, to set sth up, to assemble', összetart 'to hang/stich together, to converge', összevarr 'to sew/stitchsth up/together', összeházasodik 'to marry sb, to get married' (MAEK). The meaning of 'setting parts apart', on the other hand, is expressed by co-verbial constructions such as szétszerel 'to take sth apart, to disassemble', széttép 'to tear sth to pieces/bits', széttagol 'to dismember, to divide, to disunite' (MAEK).

\section{Prototypical scene No. 2}

Prototypical scene No. 2 is based on a perception of asimilar folding and unfolding movement thatis sometimes performed by our armsbut additionally includes the use of various kinds of instruments and objects. Consequently, it generates the meanings of 'collecting' and 'dispersing'.

It is interesting to observe that our body parts (arms, legs, hands, fingers) are those elements of the external world which are most closely situated to us - we always have them 'at hand'. If we use objects or instruments, they are very often perceived as extensions of our hands and other body parts. Our analysis of co-verbial constructions based on össze/szét modifiers suggests that prototypical scene No. 2 motivates, for example, the opposition between the verbs összegyüjt 'to collect' and szétszór 'to scatter, to disperse,' where the collected objects are conceptualized as elements of the external world manipulated by our body parts or their extensions and which are being 'put together' or 'set apart'. Their meaning can be illustrated by the following sentences:

(10) Összegyüjtötte a skóciai nép még kelta korú énekeit. 'He collected Scottish songs from the Celtic period.' (HNC) 
The cognitive motivation behind the semantics of Hungarian co-verbial...

(11) Egyszer a király összegyüjti a birodalmában levő mágnásokat. Once the king gathers magnets from his realm.' (HNC)

(12) Az Agora igyekszik összehoznia az embereket, közös akciókat, kirándulásokat, túrákat szervezni gyerekeknek és felnötteknek egyaránt. 'Agora strives to bring people together, organize activities, excursions, and hikes for children and adults alike.' (huTenTen12)

(13) Szétszórja a pénzt. 'She/He throws money around.' (HNC)

(14) Szétszórja a negatív energiákat. 'She/He radiates negative energies.' (HNC)

(15) Ha széttörik a tablettát, megváltozhat a hatása. 'If you crack the tablet, its effect may change.' (huTenTen12)

The Sketch Engine Concordance provides 67,570 contexts for the coverbial construction összegyüjt 'to collect' (21.37 per million), 27,904 contexts for gyüjtössze (8.83 per million) and 189 contexts for összegyüjt (0.06 per million) compared to non-co-verbial gyüjt 'to collect' with 183,937 contexts (58.17 per million). The most frequent collocations with the coverbial összegyüjt 'to collect' include: darabokat 'pieces', anyagokat 'materials', információt 'information', adatokat 'data', hulladékot 'waste', szemét 'trash', játékokat 'games', kellékeket 'props', válaszokat 'answers', cikket 'articles', pénzét 'money'.

In the case of the co-vebial construction szétszór 'to scatter, to disperse', the Sketch Engine Concordance provides 8,397 contexts (2.66 per million) for szétszór, 2,663 contexts (2.66 per million) for szórszét, and 45 contexts (0.01 per million) for szétszór compared to non-co-verbial szór 'to scatter, to disperse' with 47,354 contexts (14.98 per million). The fact that in the case of the two verbs - összegyüjt 'to collect' and szétszór 'to scatter, to disperse' - the meanings of the co-verbial constructions and theirnonco-verbial variants (themain verb without a co-verbial modifier) so closely correspond to one another, suggests that the verbs themselves express meanings closely related to the meanings of the co-verbial modifiers - össze/szét - and that is why they have been chosen as typical representatives for prototypical scene No. 2. HNC and huTenTen12 provide a number of contexts where the two co-verbial constructions are used together in one sentence, e.g.:

(16) Összegyüjti a szétszórt ruhákat. 'She/He is collecting scattered clothes.' (huTenTen12) 
(17) Ha pedig le akarnád rombolni, amit épitettem, vagy szétszórni, amit összegyüjtöttem, kétségkíül igen nagy kárt szenvedne országod. 'And if you were to destroy what I had built or scatter what I had collected, your country would undoubtedly suffer greatly.' (HNC)

(18) Aki velem van: összegyüjt - aki ellenem: szétszór. 'Whoever is with me collects - who is against me scatters.' (HNC)

The opposite meanings of 'collecting' and 'scattering', cognitively motivated by prototypical scene No. 2, can be observed in a number of additional co-verbial constructions with össze/szét such as összeszed 'to collect, to gather, to get sth together', összehord 'to bring sth together, to gather (together), to collect', összeállit 'to assemble, to put together', szétszalad 'to run in all directions, to run all over the place, to scatter', szétloccsan 'to spatter, to splash', szétterpeszt 'to spread', szétzilál 'to disarrange, to make a mess of sth' (MAEK).

\section{Prototypical scene No. 3}

Prototypical scene No. 3 can be treated as a metonymic elaboration of prototypical scene No. 2 and prototypical scene No. 1 as it continues selected elements ofboth scenes while dropping some of their other properties. More specifically, in the case of össze, with its typical meaningof 'joining parts together', only the second element of its meaning - 'together', i.e. two sides being confronted or put together - is continued in scene No. 3. The meaning of parts being joined or united is dropped or replaced by other activities in which the parts can be moved together or confront each other.

As far as the co-verbial modifier szét is concerned, with the meaning of 'setting parts apart', in prototypical scene No. 3, it continues the meaning of the second element - 'apart' or 'all around' and 'everywhere'. This second meaning component emphasizes a long distance rather than separation or splitting. Thus, the second element moves to the forefront while the first element is dropped. In other words, prototypical scene No. 3 highlights only selected elements of the previous scenes. The meanings of 'together' and 'long distance' become salient and motivate new meanings evidenced in the contexts of össze/szét co-verbial constructions..$^{9}$ This process can be illustrated by the following examples:

(19) Angol és orosz szurkolók csaptak össze csütörtökön éjszaka Marseilleben. 'English and Russian fans clashed in Marseille on Thursday night.' (huTenTen12) 
The cognitive motivation behind the semantics of Hungarian co-verbial...

(20) Az ország legjobb fiatal kémikusai csaptak össze. 'The country's best young chemists competed together.' (huTenTen12)

(21) A két fiú összeverekedik a csajért jelenet nem volt túlságosan jellemző rám. 'The scene of two boys quarreling about a girl was not too typical of me.' (huTenTen12)

(22) Beszéd közben Daku szétnézett a polgári lakásban. 'As he spoke, Daku glanced around the civilian apartment.' (HNC)

(23) Vastag hullámban tört elő a büz, szétterjedt az egész helyiségben. 'A thick wave of stink erupted, spreading across the room.' (HNC)

(24) Most pedig szétvisszük a világ minden tája felé a szeretet evangéliumát. 'And now we are spreading the gospel of love to all parts of the world.' (HNC)

(25) Kisérletképpen pilóta nélküli repülő szerkezettel spricceltek szét vegyszert a Zanzibár szigeten a malária megelözése céljából. 'As an experiment, chemicals were sprayed by an unmanned aerial vehicle on Zanzibar Island to prevent malaria.' (huTenTen12)

Further evidence for the motivational impact of prototypical scene No. 3 is provided by the semantic structures of co-verbial constructions such as összevész 'to quarrel, to have a row with sb', összeveri a tenyerét 'to clap one's hands', összezárvkitvkivel 'to shut, lock sb up together with sb', összebarátkozik 'to make friends with sb', szétküld 'to send off/out', szétlop 'to steal (all the time)', szétterít 'to spread out', szétárad 'to flood everything' (MAEK).

\section{Prototypical scene No. 4}

In prototypical scene No. 4, the physical meaning of 'closely', 'tightly', 'being close to one another' expressed by the co-verbial modifier össze is changed into 'completely', 'thoroughly'. A similar process can be observed in the case of szét, but here, instead of the spatial relation of SHORT/CLOSE DISTANCE, the source domain is the opposite spatial relation of LONG/FAR DISTANCE. As a result, both co-verbial modifiers begin to function as intensifiers in co-verbial constructions such as the ones illustrated by the following contexts:

(26) Ha az étrendünk kiegyensúlyozatlan, rendszertelenül eszünk, ráadásul összezabálunk mindenféle cukros szemetet, akkor jön a rettegett háj. 'If our diet is unbalanced, we eat irregularly, moreover we stuff our- 
selves with all sorts of sugary junk food, then comes the dreaded lard.' (huTenTen12)

(27) Ez a ruha is csúful összeázott tegnap abban a nagy zivatarban. 'This dress got completely wet in that big thunderstorm yesterday.' (HNC)

(28) Az épületek falai összefirkáltak. 'The walls of the buildings were scribbled all over.' (HNC)

(29) Kalapáccsal verte szét a nö fejét. 'He beat the woman's head with a hammer.' (HNC)

(30) Fillérekért hajtjuk szét magunkat. 'We work ourselves to death for pennies.' (huTenTen12)

(31) Instázd szét a hosszú hétvégét! 'Document the long weekend with lots of posts on Instagram.' (huTenTen12)

In all of the above-quoted contexts, co-verbial modifiers össze/szét are used to intensify the meaning of the main verb. Because the function is the same for both modifiers, in many contexts the co-verbial modifiers can be used interchangeably; for example, összeázik 'to get soaking/dripping wet, to get wet through' and szétázik 'to soak through, to get/become soggy' (MAEK) do not show any substantial difference in meaning. Similarly, the use of co-verbial modifiers as intensifiers is visible in co-verbial constructions such as összevérez 'to stain sth with blood', összeturmixol 'to blend thoroughly', összenyom 'to squeeze', összezavar 'to baffle, to confuse', szétrombol 'to destroy, to shatter, to demolish' (MAEK).

\section{Discussion and concluding remarks}

The study presented in thispaper shows that the use of Hungarian coverbial constructions is not arbitrary; instead, it should be conceived of as, first and foremost, cognitivelly motivated. Co-verbial constructions are higly polysemous and the network of the multiple semantic extensions they produce can be shown to be motivated by a limited number of prototypical scenes and closely associated conceptualizations. These prototypical scenes are semantically prominent categories. Other entities are seen in relation to them and they act as cognitive reference points guiding their use.

Cognition plays a central part in the motivation of Hungarian co-verbial constructions. In fact, all of the four prototypical scenes described here are grounded in the bodily experience of moving one's arms toward and away from the body's center. This kind of bodily movement is metonymically transferred to other body parts as well as to various instruments/objects. 
It is also metaphorically projected onto other, more abstract domains, which leads to the extension of the first prototypical scene and, consequently, creates a number of related variations of the prototypical scenes.

As a result, a network of polysemous meanings is developed in the form of a radial category which has a dynamic character and resembles a lexicalization cline - the extended scenes are increasingly more abstract and ultimately, in the final stage such as prototypical scene No. 4, motivate completely delexicalized items. Consequently, previously fully lexical units tend to express mainly pragmatic functions and the co-verbial modifiers beginto act as intensifiers. At this point, the functions of both össze and szét seem to overlap and they can be used interchangeably. The process itself is very reminiscent of cases of grammaticalization and its clines as described in Heine (1997) and Heine and Kuteva (2002).

However, as observed by de Saussure (1916), motivation is always relative. Langacker (2011) characterizes motivation as a middle-ground position between the idea that language is determined by universal and predictive rules and the idea that languages can differ in countless ways. The view that language is motivated implies that it is neither fully predicable nor fully arbitrary.

For these reasons, the patterns of cognitive motivation presented in the foregoing should not be regarded as universal rules governing the use of össze/szét co-verbial constructions in Hungarian, but rather as general tendencies that may prove to be useful both for learners of Hungarian and translators. For example, in the contexts quoted below the knowledge of the meaning of the co-verbial modifiers and prototypical scenes that cognitively motivate them may be crucial for arriving at their correct interpretation:

És akkor Torma elkezdte mondani, amit a könyvtárban a lexikonból meg az ismeretterjesztö könyvekböl összeolvasott. 'And then Torma began to say what she had read in the library from the lexicon and the educational books.' (HNC)

(33) Az eredeti szöveg kézzel íródott, olyan papírra, amely kora miatt nem sokkal az átírás után teljesen szétmállott. 'The original text was handwritten on a piece of paper that, due to its age, completely moldered away after rewriting.' (huTenTen12)

In (32), the appropriate interpretation is motivated by prototypical scene No. 2, which suggests that the knowledge the girl (Torma) possessed was gathered from different pieces of information - it was put together from what the girl had read about from various reference sources found in the library. Here the meaning of 'collecting', expressed by the co-verbial modifier 
$\ddot{o s s z e}$, is clearly visible and it determines the way the whole sentence should be interpreted. In (33), on the other hand, the learner of Hungarian or translator does not have to be aware of the meaning of the main verb - mállott 'weathered' - in order to correctly interpret the meaning of the whole context if $\mathrm{s} /$ he knows that one of the prototypical meanings of the co-verbial modifier szét is associated with the image of 'falling apart, dispersing'. These examples seem to suggest that the knowledge of the cognitive motivation behind the use of Hungarian co-verbial constructions can have a number of pedagogical and practical applications which, by all means, should be further explored in future studies.

\section{N O T E S}

${ }^{1}$ Hungarian belongs to the Ugric branch of Finno-Ugric languages within the Uralic family. Its closest relatives are Mansi and Khanti (both of which also use a co-verbial system), with ca. 30,000 and 10,000 speakers respectively. Hungarian has ca. 13-14 million speakers, of which approximately 10 million are located in Hungary; most of the rest live in the neighboring countries of Romania, Slovakia, Serbia, and Ukraine (Kenesei et al., 1998). Like other Uralic languages, Hungarian is an agglutinative language, while Indo-European languages are inflectional and rely on prepositions. Hungarian uses suffixing almost exclusively. The exception to the Uralic suffix-only pattern is the Hungarian system of co-verbial constructions. However, the behavior of the co-verbial modifiers is 'clitic-like' rather than 'affix-like' in that they appear after the verb when there is, for example, a preverbal focus constituent or a negative particle (Thomason, 2005).

2 http://corpus.nytud.hu/mnsz/index_eng.html

3 https://www.sketchengine.eu/hutenten-hungarian-corpus/

${ }^{4}$ In Hungarian, the term igekötök (lit. 'verb binders') is used to designate mainly coverbial modifiers (co-verbs), but sometimes also co-verbial constructions. The term coverbs is used, for example, by Rounds (2001). Kiss (2002) refers to these complex language units as verbal prefixes and prefix + verb combinations and in Kiss (2008) they are called verbal particles. Tolcsvai Nagy (2015) prefers to use a more precise term - igekötó + igeszerkezet 'co-verb + verb structure'. Surányi (2009) and Knittel (2015) call them preverbs. Knittel (2015) claims that the term preverbs is more suitable here because it describes a class of preverbal elements that differ from prefixes by their detachability.

5 At the level of the lexical aspect, co-verbial constructions in Hungarian indicate that a process is bound and function as telicity markers; when modifying grammatical aspect, they mark perfectivity (Knittel, 2015; Kardos, 2016).

6 The list contains only selected examples of co-verbial modifiers used in Hungarian. Compare also Rounds (2001), Kiss (2002) and Grygiel (2018a).

7 See also Grygiel (2018b), (2019).

${ }^{8}$ For example, Mroczko (1989, p. 379) provides the following sentences: Tegye szét a karját! 'Put your arms apart!' A labát húzza össze! 'Pull your legs together!' and illustrates them with the corresponding body partmovements.

${ }^{9}$ In contrast to prototypical scenes 1 and 2, prototypical scenes 3 and 4 can be treated as further extensions from the main core image (arm-movement) and thus they are not easy to present by means of the most typical co-verbial constructions as was done in the previous scenes. As a result, a quantitative analysis based on corpus concordances comparable to those given for prototypical scenes 1 and 2 cannot be provided. 
The cognitive motivation behind the semantics of Hungarian co-verbial...

S O UR C E M A T E R I A L

$\mathrm{HNC}=$ Hungarian National Corpus. Retrieved from http://corpus.nytud.hu

huTenTen12 = Hungarian Web Corpus 2012. Retrieved from https://www.sketch engine.eu

MAEK = Varga, G., \& Lázár, A. P. (2012. Magyar-angol egyetemes kéziszótár. Szeged: Grimm Kiadó.

MNÉS = Bárczi, G., \& Országh, L. (Eds.). (1959-1962). A magyar nyelv értelmezo" szótára (Vols. 1-7). Budapest: Akadémiai Kiadó. Retrieved from https://www.arcanum.hu

\section{R E F E R E N E S}

Biber, D., \& Conrad, S. (1999). Lexical bundles in conversation and academic prose. In H. Hasselgard \& S. Oksefjell (Eds.), Out of corpora (pp. 181-190). Amsterdam: Rodopi.

Fillmore, C. (1985). Frames and the semantics of understanding. Quaderni di Semantica, 6, 222-254.

Grady, J. E. (1997). Foundations of meaning: Primary metaphors andprimary scenes (Ph. D. dissertation). Berkeley, CA: University of California, Berkeley.

Grady, J. E., \& Johnson, C. R. (1997). Converging evidence for the notions of subscene and primary scene. Proceedings of the Annual Meeting of the Berkeley Linguistics Society, 23(1), 123-136.

Grygiel, M. (2018a). Co-verbs in specialized texts. In M. Grygiel, M. Rzepecka \& E. Więcławska (Eds.), Specialist communication in education, translation and linguistics (pp. 135-147). Rzeszów, Poland: Wydawnictwo Uniersytetu Rzeszowskiego.

Grygiel, M. (2018b). Phrasal verbs in the translation of specialized texts. Komunikacja Specjalistyczna, 15-16, 177-190.

Grygiel, M. (2019). Comparing and contrasting Polish with Hungarian co-verbial constructions. In M. Grygiel \& R. Kiełtyka (Eds.), Cognitive linguistics in the year 2017 (pp. 172-184). Frankfurt: Peter Lang.

Heine, B. (1997). Cognitive foundations of grammar. New York: OxfordUniversity Press.

Heine, B., \& Kuteva, T. (2002). World lexicon of grammaticalization. Cambridge: Cambridge University Press.

Imrényi, A., Kugler, N., Ladányi, M., Markó, A., Tátrai, S., \& Tolcsvai Nagy, G. (2017). Nyelvtan. Budapest: OsirisKiadó.

Kardos, É. (2016). Telicity marking in Hungarian. Glossa: A Journal of General Linguistics, 1(1), 41. http://doi.org/10.5334/gjgl.52

Kenesei, I., Vago, R., \& Fenyvesi, A. (1998). Hungarian. (Routledge Descriptive Grammars series). London: Routledge. 
Kiss, K. (2002). The syntax of Hungarian. Cambridge: Cambridge University Press.

Kiss, K. (2008). The function and the syntax of the verbal particle. In K. Kiss (Ed.), Event structure and the left periphery: Studies on Hungarian (pp. 1755). Berlin and New York: Springer.

Lakoff, G. (1987). Women, fire, and dangerous things: What categories reveal about the mind. Chicago: University of Chicago Press.

Langacker, R.W. (2011). Semantic motivation of the English auxiliary. In K.U. Panther \& G. Radden (Eds.), Motivation in grammar and the lexicon (pp. 29-48). Amsterdam and Philadelphia: John Benjamins.

Lehmann, C. (2007). Motivation in language. In P. Gallmann, C. Lehmann \& R. Lühr(Eds.), Sprachliche Variation. Zur Interdependenz von Inhalt und Ausdruck (pp. 100-135). (Tübinger Beiträge zur Linguistik, 502). Tübingen: G. Narr.

Lewandowska-Tomaszczyk, B. (2007). Polysemy, prototypes, and radial categories. In D. Geeraerts \& H. Cuyckens (Eds.), The Oxford handbook of cognitive linguistics (pp. 139-169). Oxford: Oxford University Press.

Knittel, M. L. (2015). Preverbs, aspect and nominalization in Hungarian. Recherches Linguistiques de Vincennes, 43, 47-76. doi: 10.4000/rlv.2245

Mroczko, E. (1989). Język wegierski dla poczatkujacych. Warsaw: Wiedza Powszechna.

Nuyts, J. (2007). Cognitive linguistics and functional linguistics. In D. Geeraerts \& H. Cuyckens (Eds.), The Oxford handbook of cognitive linguistics (pp. 543565). Oxford: Oxford University Press.

Panther, K.-U. (2013). Motivationin language. In S. Kreitler (Ed.), Cognition and motivation: Forging an interdisciplinary perspective (pp. 407-432). Cambridge: Cambridge University Press.

Panther, K.-U., \& Radden, G. (Eds.). (2011). Motivation in grammar and the lexicon. Amsterdam and Philadelphia: John Benjamins.

Radden, G., \& Panther, K.-U. (Eds.). (2004). Studies in linguistic motivation. Berlin: Mouton de Gruyter.

Rákosi, G., Laczkó, T., \& Csernyi, G. (2011). On English phrasal verbs and their Hungarian counterparts from the perspective of a computational linguistic project. Argumentum, 7, 80-89.

Rosch, E. (1973). Natural categories. Cognitive Psychology, 4, 328-350.

Rounds, C. H. (2001). Hungarian: An essential grammar. London and New York: Routledge.

Sass, B. (2008). The verb argument browser. In A. Horák, I. Kopecek, K. Pala \& P. Sojka (Eds.), Proceedings of the 11th International Conference on Text, Speech and Dialogue (pp. 187-192). Berlin and Heidelberg: Springer.

Saussure, F. de.(1916). Course de linguistique générale. (Edited by Ch. Bally and A. Sechehaye). Lausanne and Paris: Payot. 
The cognitive motivation behind the semantics of Hungarian co-verbial...

Schmid, H.-J. (2010). Does frequency in text instantiate entrenchment in the cognitive system? In D. Glynn \& K. Fischer (Eds.), Quantitative methods in cognitive semantics: Corpus-driven approaches (pp. 101-134). Berlin and New York: Mouton de Gruyter.

Stefanowitsch, A. (2006). Words and their metaphors. In A. Stefanowitsch \& S. T. Gries (Eds.), Corpus-based approaches to metaphor and metonymy (pp. 64105). Berlin and New York: Mouton de Gruyter.

Surányi, B.(2009). Verbal particles inside and outside VP. Acta Linguistica Hungarica, 56(2-3), 201-249.

Thomason, G. S. (2005). Typological and theoretical aspects of Hungarian in contact with other languages. In A. Fenyvesi (Ed.), Hungarian language contact outside Hungary (pp. 11-29). Amsterdam and Philadelphia: John Benjamins.

Tolcsvai Nagy, G. (2015). Az ige a magyar nyelvben. Funkcionális elemzés. Budapest: Tinta Könyvkiadó.

Váradi, T. (2002). The Hungarian national corpus. In M. González Rodríguez \& C. Paz Suarez Araujo (Eds.), Proceedings of the Third International Conference on Language Resources and Evaluation (pp. 385-389). Las Palmas, Spain: LREC. 